\title{
CIVILIZATION RELATIONSHIP OF ISLAM, WEST AND EUROPE: Potential Civilization Dialogue "Peace Communication Model"
}

\author{
Eko Putra Boediman
}

\begin{abstract}
If Western civilization is synonymous with the United States of America (USA), the Islamic civilization necessarily identical to the Prophet Muhammad who began a succession of civilization by building the Nabawi Mosque in Medina 1439 years ago. In 13 American-British colonies, Anthony Benezet in 1775, founded the Human Rights' organization (HAM) to abolish slavery. Thomas Jefferson stated in the Declaration of Independence of 1776, that " human rights are inherent in all mankind". In year 622, Prophet Muhammad formulate 47 articles written in the Charter/ Constitution of Medina and became a phenomenal product of Islamic civilization. This document establishes a number of rights and obligations which contain the noble values of human rights, justice, equality, mutual respect between faiths, and so on. Thus making the society of Medina into a community unity (Ummah). Both Islamic and Western civilizations have similar foundation, the same noble values and spirit, that is "Peace". Nevertheless, the idealized peace has not taken place until now. The golden ages of Islam began with the rise of Muslim scholars with discoveries of scientific foundations, resulted from the transformation and integration between the Qur'anic verses and human intelligence. The United States has intensively embarked on the values of capitalism and its imperialism since the industrial revolution in Europe. While the era of European Renaissance is closely related to the contributions of Islamic scientists with a variety of basic scientific discoveries that led to the modernization of science and technology of the world today. These condition should make it possible for every Muslim, Western, and European civilization entity to work together and synergize for world peace and better life. This article uses the approach of equality in civilization, historical beckground and communication, to captureany possible potential cooperation and synergy between the differences and equations of world civilization. The purpose of this article is to propose a "peaceful communication model" for the betterment and peace of a better world civilization
\end{abstract}

\section{Introduction}

The relationship between the Muslim world and Christianity is very complicated and convoluted throughout its history. Geographically and historically these two religions originate from one region of West Asia. In the process of spreading these two religions influence and flourish in different areas.

Revised Manuscript Received on July 05, 2019.

Eko Putra Boediman,

Universitas Budi Luhur Jakarta - Indonesia,

1'ekosyahid@gmail.com
Islam is strong in Asia and Africa, while Christianity is developing in Europe and America [1-6]. In certain connotations, Islam is associated with the Eastern world while Christianity is associated with the Western world (Hanafi, 1999: xvi-xvii). Today, due to the mobilization and migration of its adherents, these two religious communities have truly spread throughout the region and worldwide [714].

Throughout history, there have been two major world's tragedies between Islamic civilization with Europe and the West where they are in opposite and hostile positions. First, the era of Crusades the Holy War from 1095 to 1291. This war involves three Abrahamic religions: Islam, Christianity and Judaism. Although this war is only a history, but not infrequently the romance of war is often revived, as a lighter of a sense of resentment among the adherents of these religions.Secondly, the World Trade Center tragedy on September 11, 2001 (WTC 9/11). After the WTC attack on 9/11, the United States declared war against terrorists (war on terror). The paradoxical tragedy of the WTC 9/11 we encounter today, is a perfect example of the clashes that occur between religions and seems to be related to the ideology of the crusades or even explicitly called the "millennium crusade". Of course, the above attribution is less relevant and illogical, because in addition to the distortion of historical facts, the motives of conflict between religions also differ greatly between the crusades and the present [15-24].

\section{Theoretical Background}

The correlation and fluctuation of Islamic and Western meanings are often triggered by ideological or religious issues and then spread to other spheres. Islam is understood as a religion and civilization that gives a fresh color in various ideological, economic, political, social, cultural, and so on. While the West carries a secular-liberal ideology represented by the United States, Israel and its allies, in this case Western-Christian and West-Jew. Fukuyama (1992: 211-212) assumes that Islamic teachings will only pester and limit the spread of secular-liberal ideology.

Quoting from Huntington, Mukhlas Syarkun and W. Ghorara (2004: 406), they mention several factors that resulted in clash of civilizations between Islam and the West:First, the rapid growth of Muslim populations on one side has caused an outbreak of unemployment and encouraged children and

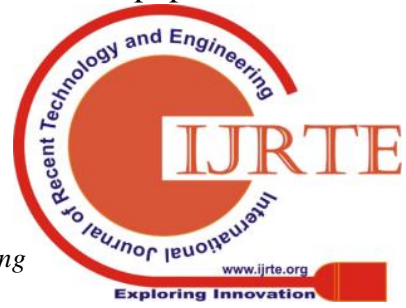


youth to become members of Islamists.Second, the rise of Islam gives new belief among Muslims to the character and nobility of civilization and its values compared to Western values. Third, simultaneous Western attempts to propagate their values and institutions, maintaining the superiority of their military and economic forces as well as intervening in the Islamic world, have resulted in resentment among Muslims.Fourth, the collapse of communism became the cause of the conviction of a common enemy between Islam and the West and to forget his past.Fifth, the relationship between Muslims and Western people encourages the emergence of a sense of identity and how to distinguish between one another.

But then, in any conflict, it is always possible to have a symbiotic mutualism between the two warring parties. Beginning in the early medieval period of Islamic civilization had already begun its contribution in the field of various sciences. The contribution of science inherited by this Islamic civilization and further developed by Western civilization, more recent and greater values for the benefit of humankind. Moreover, some of the development of science and technology today is very popular and become the basic needs for the Islamic world community.

This is where the intersection of symbiotic mutualism between the two civilizations of Islam and the West. Both civilizations are mutually contribute to the benefit and usefulness of mankind. This thinking needs to be preserved and campaigned across generations so that these two civilizations not confessing to each other ideology.They need to work together instead of competing with each other, and contribute to their best contribution for better future. Working together means helping to meet the shortcomings of each other.Conversely, competition usually indicates a negative side - powerful destroys the weak and the rich oppresses the poor. Nevertheless, competing in virtue, rightiousness and piety but don't help one another in sin and transgressionsis is highly recommended and should be a common principle among civilizations.

Democracy and Caliphate (read. Khilafah) - Peace Tool. The origin of the word "Democracy" is from the Greek ie, demos (people) and kratos (leadership), but we are familiar with the term democracy because it is promoted by Western civilization, and we know the term Khilafah because it is promoted by Islamic civilization (red: though not all Muslims agree with the Caliphate). But the point of this discussion is, whatever ideology carried outby any civilizations should hold the principle as follow:

لا إكر اه في الدين (no compulsion in religion). This principle is in the Qur'an(2: 256). If "religion" can be interpreted as ideology, principles, concepts, values, or worship, then as a good Islamic ummah should have reinforce and adhere to the principle. The author suspects, perhaps with similar text, contextual and themes, the West also has a principle similar to "laa ikroha fiddiin".For example by carrying the values of the Declaration of Independence; mutual respect and appreciation of the dignity and others' opinions as well as fully recognize human rights.

If the Western society admit theirnoble Declaration of Independence, they must also reinforce and adhere to such a noble principle universally. So that both Islamic and
Western civilization by carrying their ideology and promoting their respective strategies of each other stick to this values and norms of this noble principles, then at least they have contributed to world peace.

Whilst democracy is promoted by the West and the Khilafah is promoted by Islam. one of the best strategy to promote a good political communication such as; not forcing its will and ideology, does not harm and does not destroy nature and mankind. This is called by understanding and safeguarding rights and duties as citizens of the world. The author named it "Marketing Peace Political Communication".

According to Cuber, conflict is a process of struggle against values and demands for status, power, and resources, whose primary purpose is to offer, injure, and eliminate competitors. Newcomb also acknowledged inter-group conflicts. When discussing the issue of interaction between groups, Newcomb sees the hostility that each party has. The groups, he argued, viewed each other as the other and this hostility was constantly nurtured and defended. Furthermore, not infrequently also if this hostility attitude appears in various acts of violence.

\section{The Crusades}

According to Amstrong (2003: 27-28), in the spring of year 1096, 60,000 Christians made up of soldiers and pilgrims set out for Jerusalem. Following the next wave of more than 100,000 men, pastors and pilgrims. Urban Pope II's powerful and inspiring call became a question of its own. Because according to Karen Armstrong, crusade is very attractive to all classes of society, ranging from popes, kings, nobles, priests, soldiers and even farmers. Motives are vary, ranging from ideological to pragmatic. However, not a few are motivated ideologically and religiously. Karen illustrates the religious spirit as follows:

"People sell everything they have as a provision in a long, dangerous expedition. Most of them are not inspired by the lust of material gain. They are gripped by religious passion. They sewed the sign of the cross on their shirts and marched to the ground where Jesus died to save the world. The journey is a pilgrimage of devotion and war of enmity ". (Amstrong, 2003: 28).

Hitti (811) argues, in general the argument of Pope Urban II to drive Christians to the Crusade is; "this is the reaction of Christians in Europe to Muslims in Asia, who have attacked and controlled Christian territory since 632, not only in Syria and Asia Minor, but also in Spain and Sicily."

Meanwhile, Alatas (2012: 36-37) says, another psychological affirmative of Pope Urban II campaigned for the crusade. The first event, the conquest of Sicily and Southern Italy by the Norman Nation led by Roger (d.1101) and Robert Guiscard (d.1085). This region was originally controlled by the Muslims for more than 2 centuries. The second event was the conquest of Toledo by the Castile Kingdom in Spain in 1085. Toledo is also one of the centers of Islamic civilization in Andalusia (Spain). These two areas then became Christian domains. These two events, though not a direct factor of the crusaders, would be sufficient

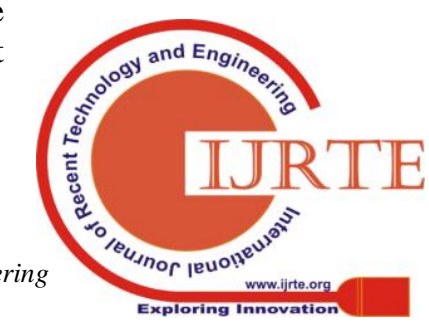


to encourage or motivate Pope Urban II to crusade.

Raschietti (2010), stated that "Jerusalem has to be free and God has to be loved." This statement affirms that the crusades contain a variety of motives of interest and pragmatic worldly. The Crusades do not represent the pure and autonomous Holy War offerings to God. Historical facts from various sources prove that there is a motive to maintain position and influence, political motives of territorial expansion, and economic motives. Sivan in Carole Hillenbrand (2007: 301) explains that the crusade is an ideological struggle (jihad), but the element of jihad always runs parallel with many other factors such as the spirit of expansionism, military political interests, xenophobia, economics and fear of attacks Europe.

The main motivation of Pope Urban II was the attempt to affirm the authority of the Roman Church as the supreme center of Church authority in the world. The use of issues about the occupation of the holy city of Jerusalem and the disruption of Christian pilgrims to Jerusalem is very effective because it is certain that this issue is sensitive to the religious emotions of Christians. It is therefore very easy for Pope Urban II to mobilize support from various parties.

Justification that the crusade is a sacred war of sacred offerings for God whose soul or spirit must be perpetuated until now is misguided. Any war even in the name of God, still begins with a variety of motives and interests.

\section{Tragedy of WTC (9/ 11/ 2001)}

In response to the attack of WTC 9/11, George W. Bush shortly gave his state statement without strong evidence that the WTC 9/11 tragedy was an Islamic terrorist with its organization involved called al-Qaeda. This is certainly a big question for the Islamic world, it can be used by small groups to blow up the WTC building symbol of America's economic hegemony. Besides, there are a lot of world figures both Muslims and non-Muslims who mention the problem and distrust that the "terrorist Islam" al-Qaeda network is the one who planned and did this all. Then came the various pros and cons of conspiracy theories and allegations.

Entering the 21st century, the relationship between Islam and the West suffered greatly from differences in the pre and post WTC 2001 period. The WTC building is an icon of US economic hegemony while also providing a stage for the popularity of militant Islamic movements, despite the fact that the militant Islamic "As the mastermind. Jervis (2002: 37-54) writes that Al-Qaeda in particular and "Virtual Universities for Future Islamic Radicalism - VUFIR" are generally accused of being the main perpetrators of the tragedy. Maftuh (2004: 566), there are 35,000 Muslims from 43 Muslim countries from the Middle East, North and East Africa, Central Asia and East Asia including Indonesia between 1982-1992, they are militant and radical Muslims. Of all these members were asked to wage war with a high jihad spirit against the Soviet Union regarded as "Atheism State" in the eyes of the mujahidin and "Communist Peril" in the eyes of the United States. America needs a "weapon" to win against the Soviet Union and this scenario is very fitting for it. Hillary Clinton's testimony to US congress (aired by CNN) that the USA funded Al-Qaeda, Taliban and imported Wahhabi.

There is some significant implicative arised after the WTC tragedy of September 11, 2001. That Muslims are suspected as the perpetrators of the controversy. First, there is considerable suspicion in various parts of the world that leads to the term 'islamophobia', especially those suspected of being terrorist and fundamentalist Islam. Secondly, in certain countries, where are friends and where are the opponents measured by the presence or absence of terrorism issues in the country. Third, the tragedy of WTC 9/11 serve as a pretext and symbol in crushing suspected terrorist nest networks. In this case, the United States becomes the driving force with its jargon of "combating terrorism" (Maftuh 2004: 556). As a result, the term "terrorism" is only used not for any other religions but Islam.

\section{Cooperation and Tolerance Among Islam, West and Europe}

In principle, Islam, the West and Europe have the potential and the ability to build tolerance. Understanding tolerance can be mutual respect, expressing views and opinions, behaviors, customs, beliefs, etc. that are different or contradictory between the two parties. Concrete examples of co-existence and cooperation between Muslim and nonMuslim groups are contained in the Medina charter formulated by the great Prophet Muhammad. The Madinah Charter is a statement that explicitly governs the common life among Muslims, Christians and Jews.

Cooperation between Islam and the West for example, in the 8th century AD when the Mediterranean Sea and trade in the region were successfully controlled by the Muslims of Byzantine and Europeans, the two sides could still trade well. Mutual cooperation in meeting the needs of each party is part of the cooperation mechanism, which in it contains a mutually beneficial exchange process, Johnson (1990: 57).

Another example of some historical events between Islam and the West is closely related to cooperation, tolerance, and coexistence. Among the agreements between Charlemagne and Harun al-Rashid concerning the handling of pilgrims in Jerusalem, the harmonious inter-civilization tolerance that occurred in Andalusia between 756 and 1000 AD. and also when Toledo, in the 12th century, became a center of study attended by scholars from all over Europe. In Esposito (2002: 3).

Another case of tolerance practiced by Muslims is when the City of Jerusalem was overrun by Caliph Omar bin Khattab. Caliph Umar through the Aelia agreement divides the Jerusalem area into three parts for Muslims, Jews and Christians. But a few centuries later the situation changed when Pope Urban II rekindled the Crusades and occupied Jerusalem and drove out the Muslims and Jews, and so on for centuries. At this time the Jews for decades gradually took control of Jerusalem by force and inhumanity. Through Donald Trump, wanting to acknowledge unilaterally that Jerusalem was the capital of Isreal by moving the American embassy to Jerusalem.

Herein lies the sincereness and greatness of Muslims

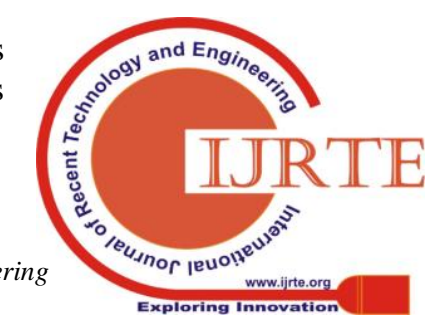


demonstrating the noble values of civilization as a contribution for better future world peace. The author proposes,among these three civilizations should realize and return or may possible to have better mutual formulation based on the agreement of Aelia or also known as Omar Convention signed on 20 Rabiul Awwal 15H (5 February $636 \mathrm{M})$.The witness to this Aelia agreement are Khalid ibn al-Walid, Amr ibn al -Ashsh, 'Abdurrahman Ibn' Awf, and Mu'awiyah Ibn Abi Sufyan. The agreement is essentially dividing the area of Jerusalem into three regions. Caliph Umar wanted to invite Muslims to uphold the rights of Christians and Jews. According to the Islamic historian Firas Alkhateeb, Aelia's treaty was the most progressive in the history of Jerusalem, compared to when Jerusalem was conquered by Persia Byzantium 23 years before the Aelia treaty, a general massacre at the behest of the authorities. Other massacres also occurred when Jerusalem was conquered by the Crusaders of the Muslims in 1099.

In conclusion, the Aelia agreement or so-calledthe Umar Convention became a track record of undeniable islamic historical evidence. That the power of Islamic civilization is proven to have a dimension of building and caring for civilization with the value of peace and the value of Rahmatan lil 'aalamiin, namely as a mercy for the entire universe.

\section{Model of Peace Communication}

Fears and concerns between one country and another about power, the seizure of energy and resources are the main causes of conflict and warfare across countries in the world. The greed of state elites and global rulers eliminates the common sense that every human being is like parts of the body. Each section has its own functions and roles to help each other, work together and look after each other. So also a country likened to a household that must be kept unity. Cooperation and mutual assistance among each internal household entity should take into priority.

Western imperialism triggers conflict and makes a widening gap between the dominant group (the first class) and the dominated group. The polarization of these two groups creates arbitrariness. Dialogue between civilizations of Islam, Christianity and Judaism is always done through Interfaith dialogue which has been a global agenda for several decades. Furthermore, in 1999 the Indonesian Youth Association of PCMI (Association of International Youth Echange Programs), held an interfaith dialogue "Building Peace Through Global Understanding" on Kemendikbud RI cooperation with CIDA (Canadian International Development Agency) to promote peace on the international scene.

James Petras and Henry Veltmeyer (2002: 217) commented that the discourse on modernity and democracy was all actually used to legitimize colonialism, slavery, genocide, hegemony and all forms of exploitation of human beings

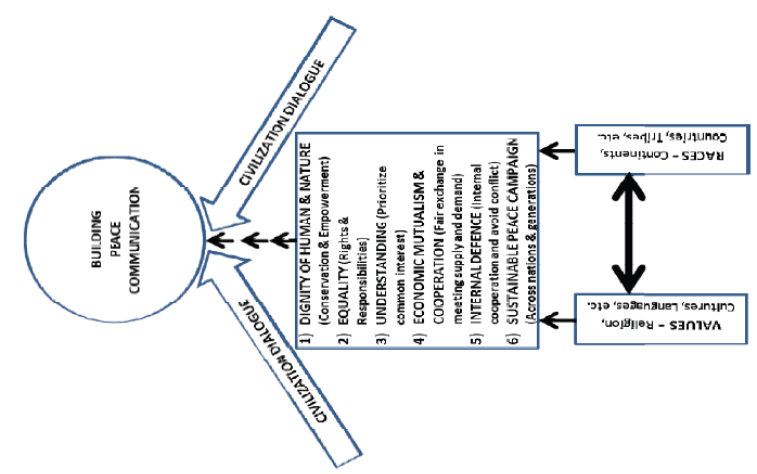

Dialogue is the interaction of communication to exchange thoughts, values, and perspective to achieve the common goal of agreement and mutual understanding. Dialogue is considered to be the least risky in resolving conflicts. In the dialogue model, the parties involved in the conflict (West non-West - Islam) are assumed to be in parallel positions to establish mutual understanding with each other. Cooperation and participation will only be meaningful if based on a balance of interests and free of hegemony.

The dialogue model is the most ideal way to resolve civilizational conflicts or interests. But his notes, that the lust of Western hegemony is something that is already latent in the tradition of Western-non-Western relations, and invites the West to be more just.

Dialogue of civilization includes between civilizations in a country or different countries. The main purpose of civilizational dialogue is: 1) exchange of cultural values for enrichment and learning of moral messages; 2) the relationship of transactional mutualism as in the field of economy and business; 3 ) discuss conflicts and warfare that occur to find the best solution between the parties to the conflict. The main mission of civilizational dialogue is the creation of peace among fellow human beings in the world by promoting peaceful communication ("Peace Communication").

Such a noble goal can possibly be implemented by using "peace communication model" perpetuated among people, across generations and across civilizations. Here is a model of Peace Communication as an alternative to the concept of dialogue of world civilization:

\section{7. "Peace Communication Model"}

\subsection{By: Eko Putra Boediman}

The "Peace Communication model" can be described in detail as follows:

1. The model resembles a human body shape because the object and subject are the dynamics of human interaction dialog.

2. The right side of the foot carries aspects of RACE Continent, Country, Tribe, etc. The left side of the foot carries aspects of VALUE - Religion, Culture, Language, etc. This foot represents the foundation, priority and fundamental aspects that are brought and ingrained within each human being as a capital interaction among human communication. The right and left legs are simultaneously synergistic

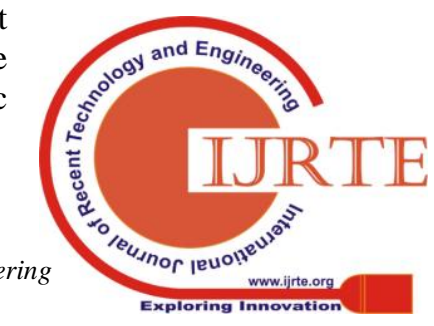


and blending which is symbolized by a two-way arrow symbol.

3. The foot part as a symbol of foundation, movement and journey brings the whole human body everywhere. Symbolized with the arrow pointing upwards.

4. There are six aspects in the body. Because the heart lies in the human body, it is ideally expected that these six aspects can be ingrained, possessed and protected by every human individual. The description is as follows:

4.1 DIGNITY OF HUMAN AND NATURE. Maintaining dignity as a human being must be empowered and provide empowerment to fellow human beings using their potential and the natural surroundings. Maintaining dignity as a 'nature' must be preserved and used wisely for only basic human needs and not for human desires.

4.2 EQUALITY. Equality of Rights and Obligations of each human being according to its portion and performance. In civilizational dialogue it is appropriate that those who have the dialogue "sitting equally low standing equally high", nothing superior or inferior. Thus, the interaction of communications being built can proceed well and to achieve solutions and common goals.

4.3 UNDERSTANDING. Must always prioritize common interests above individual interests. If it has not yet reached the understanding and agreement "give in to gain" or simply only "silence with no action" is better than having to be in conflict and fighting, it will hurt both sides. The losing party loses because the human resources and natural environment is destroyed. Meanwhile the winning party loses because the capital used for combat should be used to maximize internal defenses; welfare and prosperity, economy, entrepreneurship, etc. And of course both parties lose the lives of their citizens at productive age.

4.4 ECONOMIC MUTUALISM \& COOPERATION. Economic transactions carried out between the two countries should be carried out proportionally and professionally, no one will be harmed. Must pay attention to the surrounding environment when exploring and exploiting natural resources. Empower local communities and maintain local wisdom. The principle of cooperation (mutual cooperation) for mutual benefit, not the principle of competition where the weak are 'oppressed' by the strong.

4.5 INTERNAL DEFENSE. Strengthening national / internal resilience and building national independence, especially in key areas of human needs; economy, education, health, community welfare, etc. The strength of national security will not be underestimated or intervened by other nations and will even be respected and equal. Parallels and equivalents will create a good symbiotic mutualism between countries.

4.6 SUSTAINABLE PEACE CAMPAIGN. World peace campaigns should always be voiced systematically, comprehensively covering people,nature, and sustainable across generations (kiddy, youth, adults). Inter-generations must have the same understanding that this world is really a human shelter and must be guarded and preserved. "You can't love what you do not know", all must play a role to maintain world peace if we want our children and grandchildren to see a brighter future.
5. The part of the hand that stretches as a symbol of 'welcome', opens itself to eternal friendship and overshadows the six aspects that are inside the human body. The 'hand' represents the work of doing something through the "Civilization Dialogue" carrying and upholding the six aspects below it.An arrow pointing to the head section, having a common goal and interest of "Building Peace Communication".

6. The head is a symbol of the core of the human body's organs. Humans must always think of 'peace' for themselves, the others and the natural surroundings. Peace within oneself can reflect peace for others, and then together to nurture and preserve the natural surroundings of the world and everything inside it for the welfare and future of mankind.

\section{Conclusion (Symbiotic Mutualism Interaction of Islamic, European and Western Civilizations)}

Interaction and connectedness between the Islamic world and the West such as interactions that occur in society in general. Murray (1950) concludes that these interactions and relationships may take the form of cooperation, competition and conflict. Interaction in question is the process of mutual relationships and mutual influence, both in the form of exchange of thoughts and goods.

Furthermore, according to Murray (1950), none of the people in this world exclusively adopt only one form of interaction. For example, there is often overlap between the Islamic world and the West. Interactions that involve both simultaneously show competition, conflict and cooperation. In their daily life, these three communities of Islam and the West are harmoniously seen to live harmoniously and together, but at the same time both sides are very likely to engage in political, ideological, and economic conflicts, rivalries, and competitions.

Of the three forms of interaction (competition, conflict, cooperation), competition is the most basic and universal form. The interaction that occurs in the life of the community comes from this form. Competitions that occur can cover a very wide field such as economy, politics, military, religion and so on. Dawson was quoted as saying by Mohammed, the presence of Islam in the early 7th century $\mathrm{AD}$ has automatically been placed by Christians as their competitors.

In general, the competition takes place continuously and is impersonal. Therefore, togetherness between the Muslim world and Christianity for example, will not automatically eliminate the competition between them. In the next stage, this competition will turn into a conflict if the competition process is realized. Thus, conflict is a form of intensification of the competition which, according to Murray is not infrequently accompanied by antagonistic behavior. However, it seems rather difficult to clearly distinguish between competition and conflict because in the process there is always a combination between the two.

\subsection{Recommendation}


There are no community groups that exclusively adopt only one interaction model, even these interactions occur overlap. This also applies to the interaction between the Islamic world, Europe and the West. Both of these entities interact together between conflict and cooperation which also involves the exchange process. For example, when Muslims and European Christians were involved in the Crusades. On the other hand historical facts reveal that both parties can still establish cooperation and exchange processes, namely in the field of trade. This fact is expected to be able to reconstruct the perspective of the interaction of the Islamic world, Europe and the West. That mutually beneficial cooperation in the exchange process through the principles of 'peace communication model' can make a positive contribution to the future aspirations of world peace.

Ethical clearance - Not required

Source of funding- Self

Conflict of Interest - Nil

\section{References}

[1] Abegabriel, A. Maftuh. 'Al-Qaidah: Arabists or Islamists?', in A. Maftuh Abegebriel and A. Yanti Abeveiro (eds), Negara Tuhan: The Thematic Encyclopaedia, Jogjakarta: SR-Ins Publishing, 2004.

[2] Ahmad, Sukardja. Piagam Madinah dan Undang-Undang Dasar 1945. Jakarta: Universitas Indonesia Press, 1995.

[3] Alwi Alatas. Nuruddin Zanki dan Perang Salib. Zikrul Hakim. Jakarta, 2012.

[4] Al-Thabari, Ibn Jarir. Tarikh al-Umam wa al-Muluk. Dar al-Kutub al-'Ilmiyyah, Beirut, jilid II, hal. 449, 1997.

[5] Amstrong, Karen. Islam: A Short History. Ikon. Yogya, 2002.

[6] Cuber, John F. Sociology: A Synopsis of Principles, 5th Edition (New York: Appleton-Century-Crofts, Esposito, John L. dkk., Dialektika Peradaban: Modernisme Politik dan Budaya di Akhir Abad ke-20, terj. Ahmad Syahidah. Yogyakarta: Qalam, 2002.

[7] David Levering Lewis. The Greatness of Al-Andalus : Ketika Islam Mewarnai Peradaban Barat. (diterjemahkan dari God Crucible: Islam and The Making of Europe, 570-1215) cet. 3. PT. Serambi Ilmu Semesta. Jakarta., 2012.

[8] Esposito, John L. Islam and the West After Sept. 11: Civilizational Dialogue or Conflict? dalam The Emirates Center for Strategic Studies and Research, (Nov, 2002).

[9] Felix Y. Siauw. Muhammad Al-Fatih 1453. Khilafah Press. Jakarta., 2011.

[10] Fukuyama, Francis. 'The End of History and the Last Man'. Free Press, New York, 1992.

[11] Hafez, Kai (ED.). The Islamic World and the West: An Introduction to Political Cultures and International Relations. Koninklijke Brill, NV, Leiden, The Netherlands, 2000.

[12] Hanafi, Hassan. Oksidentalisme: Sikap Kita terhadap Tradisi Barat, terj. M. Najib Buchori. Jakarta: Paramadina, 1999.

[13] Hillenbrand, Carole. Perang Salib Sudut Pandang Islam (diterjemahkan dari The Crusade, Islamic Persfective) Cet. 3. Jakarta: PT. Serambi Ilmu Semesta. 2007.

[14] Hugh Goddard. Sejarah Perjumpaan Islam Kristen: Titik Temu dan Titik Seteru Dua Komunitas Agama Terbesar di Dunia. Serambi Ilmu Semesta. Jakarta, 2013.
[15] Johnson, Doyle Paul. Teori Sosiologi Klasik dan Modern, Jilid 2, terj. Robert M.Z. Lawang. Jakarta: Gramedia Pustaka Utama, 1990.

[16] Khadar, Lathifah. Ketika Barat Memfitnah Islam.Jakarta: Gema Insani Press, 2005.

[17] Murray, Raymond W. Sociology for a Democratic Society. New York: Apleton-Century-Crofits, Inc., 1950.

[18] Newcomb, Theodore M.. dkk., Psikologi Sosial, terj. Joesoef Noesjirwan ddk. Bandung: Diponegoro, 1978.

[19] Petras, James and Veltmeyer, Henry. Extractive Imperialism in the Americas. Capitalism's New Frontier. Brill, Leiden, 2002.

[20] Philip K. Hitti. (edisi revisi). Sejarah Ringkas Dunia Arab. Pustaka Iqra. Yogyakarta, 2001.

[21] Philip K. Hitti. History of The Arabs (Terjemahan Indonesia). PT Serambi Ilmu Semesta. Jakarta, 2008.

[22] Syarkun, Mukhlas dan Ghorara, W. "Dunia Islam dalam Benturan Kepentingan dan Peradaban", dalam Negara Tuhan: The ThematicEncyclopaedia, Yogyakarta: SR-Ins Publishing, 2004.

[23] Sassoli, Marco. Transnational Armed Groups and International Humanitarian Law. Program on Humanitarian Policy and Conflict Research Harvard University. Occasional Paper Series. Winter 2006. http://www.ihlresearch.org.

[24] Raschietti, Matteo. "Jerusalem Has to be Free and God Has to be Loved: Bernard of Clairvaux Between Second Crusade and Cistercian Mystic." Original title: "Jerusalém há de ser liberada e Deus há de ser amado: Bernardo de Claraval entre a Segunda Cruzada e a Mística Cisterciense Jerusalem has to be free and God has to be loved: Bernard of Clairvaux between Second Crusade and Cistercian Mystic." Mirabilia Journal 10: The Middle Ages and the Crusades (2010/1): No. 4.

Website

https://www.weforum.org/agenda/2015/10/how-agama-akandunia-menjadi-di-2050 /. 